\title{
"PIT CRATERS", LAVA TUBES, AND OPEN VERTICAL VOLCANIC CONDUITS IN HAWAII: A PROBLEM IN TERMINOLOGY.
}

\author{
William R. Halliday *
}

\begin{abstract}
Almost from the 1849 publication of the term pit crater, volcanologists have disagreed about the parameters differentiating these features from other vertical volcanic structures. Kaluaiki is a jameo giving entry to Thurston Lava Tube in Hawaii Volcanoes National Park. Long-standing misidentification of it as a pit crater is an example of misunderstandings arising from the lack of a clear definition of pit crater. In general, pit craters are unrelated to lava tube caves genetically, but two special cases are discussed. One probably is genetically related to a rift tube deep below the surface; the other is a complex of a small pit crater with a partial rim of accreted plates plus an ordinary-seeming lava tube cave. The term pit crater should be redefined in such a way that it excludes collapses or subsidences related to ordinary superficial lava tubes and open vertical volcanic conduits. Otherwise, a non-definition like that currently listed for agglomerate may be appropriate.
\end{abstract}

Keywords: vulcanospeleology, volcanic caves, terminology, Hawaii

\section{INTRODUCTION}

The show cave section of Thurston Lava Tube in Hawaii Volcanoes National Park is the world's most visited lava tube cave. Almost from the time of its discovery, volcanological and popular accounts have described it as entered through an opening in the side wall of a pit crater named Kaluaiki - "the little crater" - or considered one of two supposedly round "Twin Craters" (Fig. 1). Actually Kaluaiki is a sinuous two-level collapse jameo with accreted lava walls (Halliday, 1993); an upslope trench section of Thurston Lava Tube per se. An additional cavernous part of the lava tube (in Mauka Thurston Cave) lies beneath the shallow upslope section of this trench, at the end opposite the entrance of the show cave.

Kaluaiki meets the definition of jameo in the 1997 4th Edition of Glossary of Geology (Jackson, ed., 1997) and is genetically similar to such type examples as Jameo de la Gente on Lanzarote Island, Spain (Fig. 2). Some influential publications and individuals, however, continue to call Kaluaiki a pit crater, and in that new 4th Edition of Glossary of Geology the term pit crater is defined vaguely:

Pit crater: A sink [volc.] or a small caldera

Sink [volc.]: A circular or ellipsoidal depression on the flank of or near a volcano, formed by collapse. It has no lava flows or rim surrounding it.

But whether it is round or sinuous, to term a jameo a pit crater inevitably is confusing to persons interested in volcanic speleogenesis or in mechanics of lava flows in general.

\footnotetext{
* Hawaii Speleological Survey of the National Speleological Society - 6530 Cornwall Court, Nashville, TN 37205.
} 


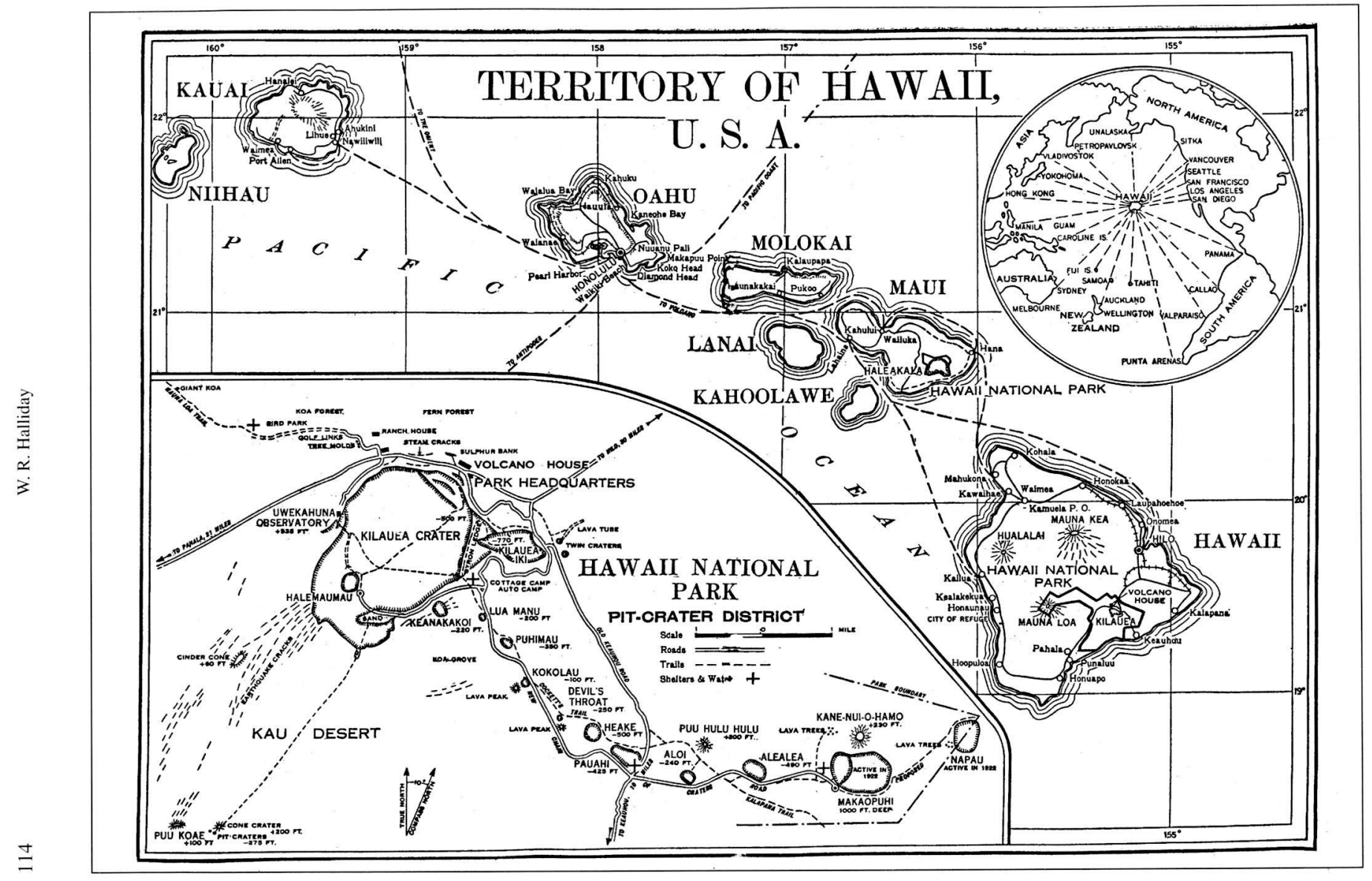


Confusion also has arisen from application of the term pit crater to other vertical volcanic structures in Hawaii. Use of that term for other collapse trenches, skylights, or sinks formed by collapse or slumping of the roof of ordinary lava tube caves probably has been the most confusing. Fortunately, the misuse of this term for ordinary spelean phenomena of this type seems to be declining. Yet it persists at least in informal usage for some deep examples close to vents (Fig. 3).

\section{CHARACTERISTICS DEFINING PIT CRATERS: PRESENT DISAGREEMENTS}

Among volcanologists there is little agreement on characteristics defining pit craters. The "Pit-Crater District" of Hawaii Island (Fig. 1,4) commonly is considered the Hawaiian type locality for volcanic pits which qualify. Many (but not all) of the volcanic pits of this area open directly downward from the surface, with no ring nor cone of ejecta nor overflow (Fig. 4). Some volcanologists exclude all pits with rims or overflows, as well as similar-appearing pits at the apex of volcanic cones (Fig. 5). Others differentiate between rimmed pits inside and outside of calderas. Within the caldera of Kilauea Caldera, Halemaumau Crater (Fig. 6) is a typical example on which there is no consensus.

Generally similar features exist on Mauna Loa Volcano (Fig. 7, 8) and Hualalai Volcano (Fig. 9-12). The morphology of these pits differs largely in their ratio of width to depth, and the degree of overhang, not in wall structure. There are, however, some special cases to be considered. Na One Pit (Fig. 11, 12) has a very small rim of ejecta, and has an inner shaft reaching a total depth of -283 meters. Kaupulehu Crater (Fig. 10 ) is a bowl-shaped crater but has an inner vertical shaft of undetermined depth. These two inner shafts are lined with accreted lava, unlike the rough, broken walls of typical pit craters, and this may serve to differentiate them as a special type of open vertical volcanic conduit as defined by Skinner (1993).

\section{PIT CRATERS AND LAVA TUBES}

Located at the head of the Keana Oa Waa complex of Hawaii Volcanoes National Park, a small volcanic pit with a downslope rim of accreted lava plates angles sharply downward into the upper end of a normal-appearing, shallowlying lava tube cave (Fig. 13). To date, this is a unique occurrence. Otherwise, pit craters and similar-appearing volcanic pits appear to have no genetic relationship with ordinary lava tube caves. The openings of deeplying lava tube caves can be seen on the walls of a few other volcanic pits. Jaggar photographed a short-lived rift tube which briefly carried overflow from Halemaumau's lava lake (Jaggar, 1947). Three apparently small lava tubes were seen on pit walls near the bottom of Devil's Throat (Doerr, n.d.) and a filled tube exists near the bottom of one of the Kau Desert pit craters (Whitfield, 1980). On Hualalai Volcano, the apparent opening of a sizable lava tube cave is visible at approximately the 40 meter level of a volcanic pit estimated to be 200 meters deep (Moore and Clague, 1991), and a smaller example exists in Na One Pit at about the 60 meter level. These examples appear to be either preexisting buried tubes incidentally exposed during development of the pit or as deeplying rift tubes formed along linear structures genetically related to the pits. Clearly, however, their presence was not the cause of the formation and development of the pits. Only one probable exception has been found to date. At the bottom of the so-called Wood Valley Pit Crater near the Kau Desert (Fig. 
Fig. 2. Upslope end of Jameo de la Gente, Lanzarote, Canary Islands, a jameo type locality. Photo by the author.

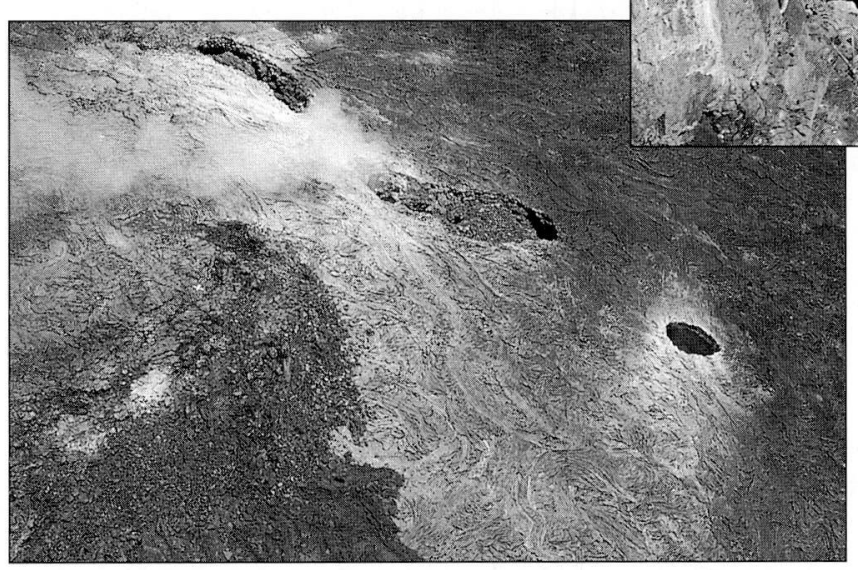

Fig. 4. Vertical section of Devil's Throat from Scribner and Doerr, n.d. The width of the surface opening now has increased to about 60 meters.
Fig. 3. Aerial view of trench segments and skylight of a large lava tube cave immediately downslope from Kupaianaha Crater. Photo by the author.

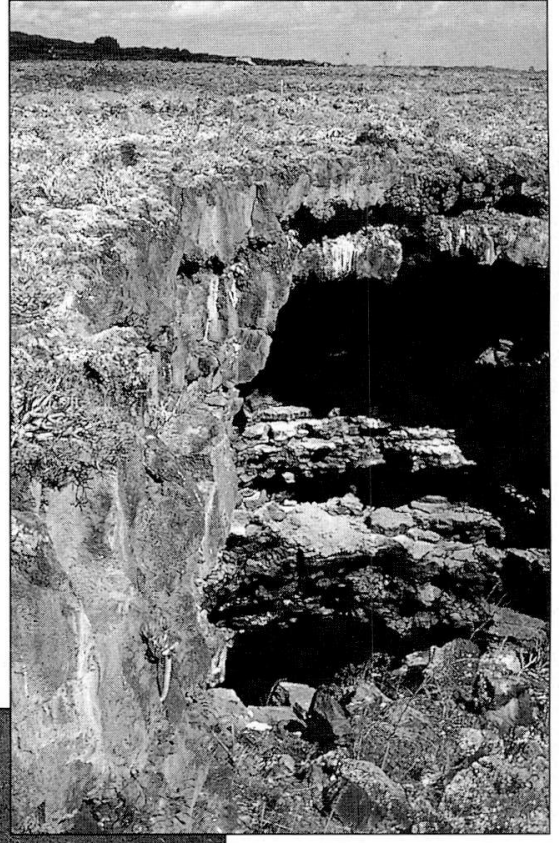




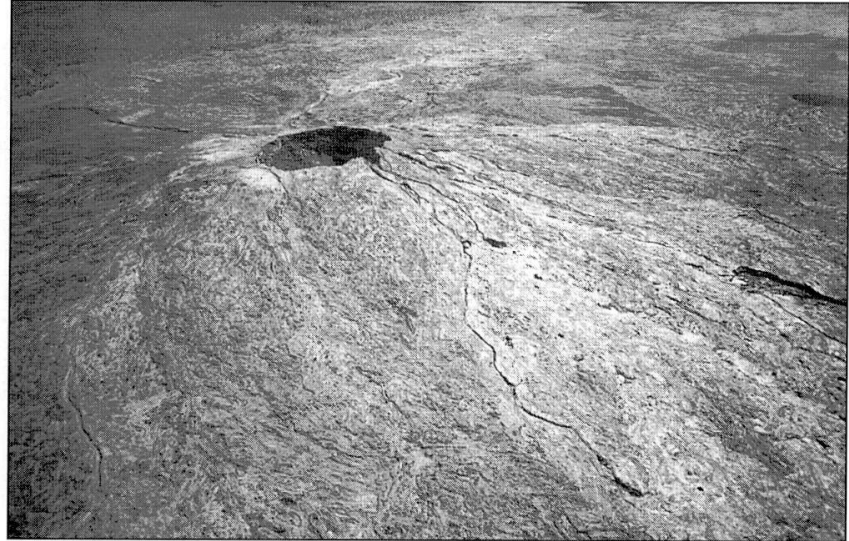

Fig. 5. Aerial view of pit at summit of Mauna Ulu, Hawaii, a composite cone. Photo by the author.

Fig. 6. Aerial view of Kilauea Caldera showing Halemaumau Crater, considered by some volcanologists to be a pit crater. Photo by the author.

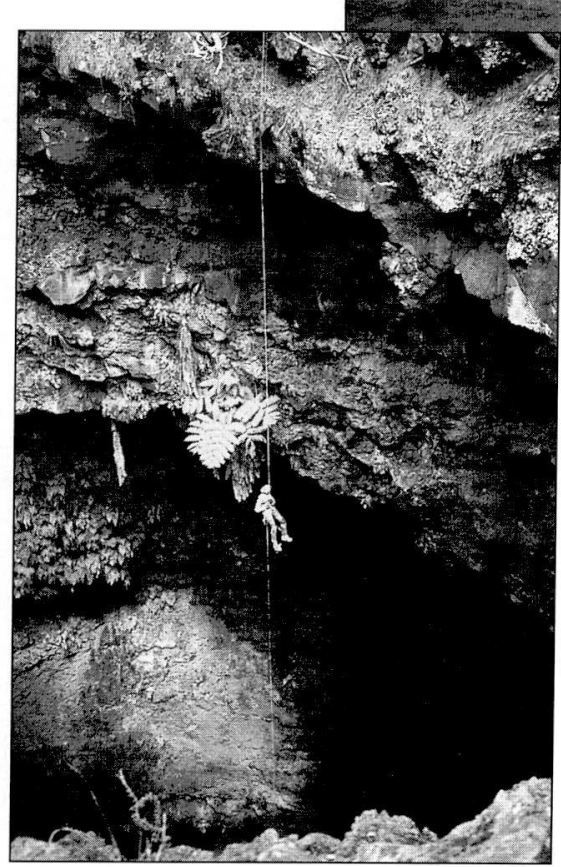

Fig. 7. Hapai Mamo Pit, southwest rift zone of Mauna Loa volcano. Photo by the author 


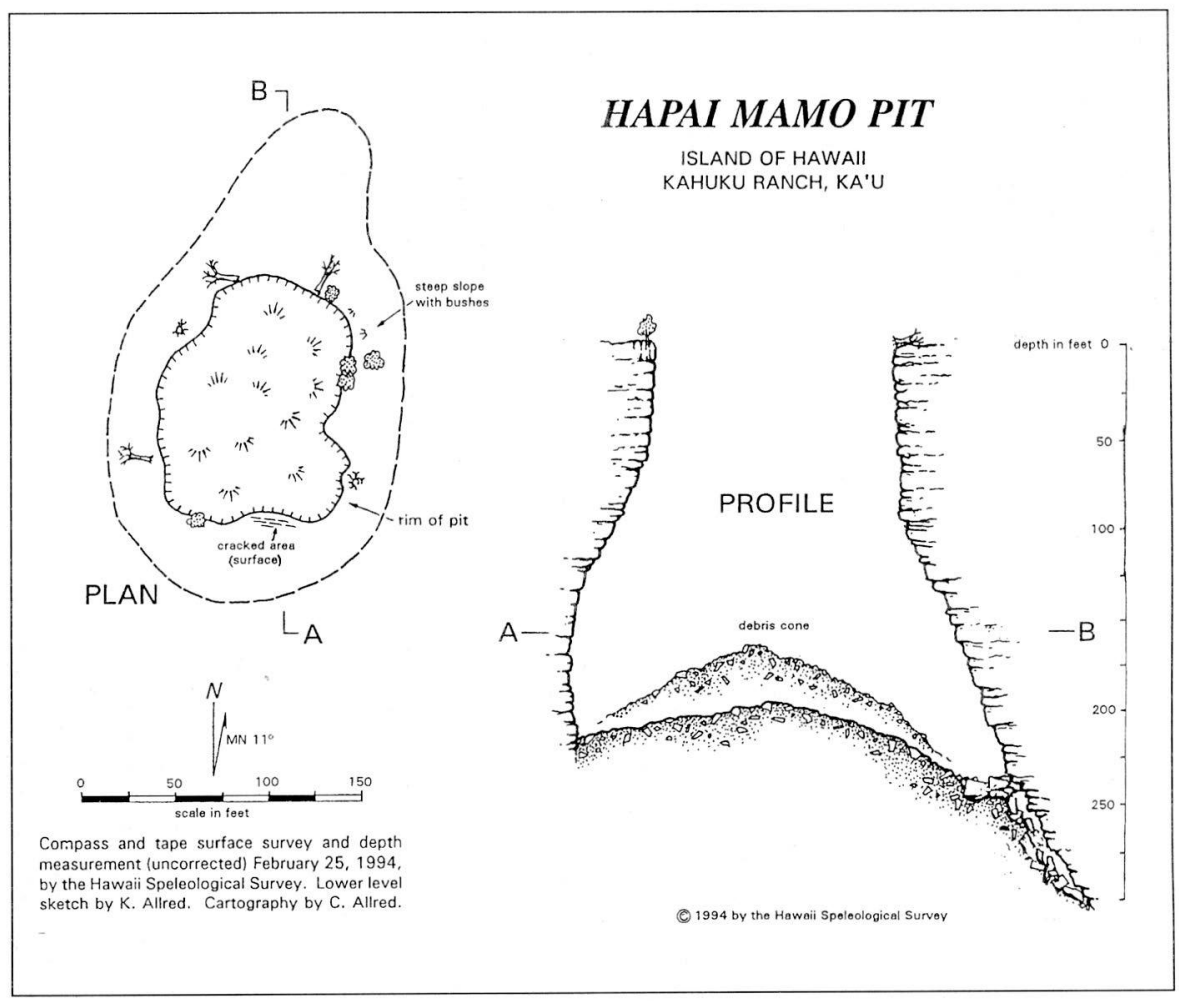

Fig. 8. Map of Hapai Mamo Pit, Island of Hawaii, Kahuku Ranch, Ka'u.

14) a rift tube 620 meters long exists about 85 meters below the surface, at the bottom of the pit structure (Favre, 1993). Upward stoping from this rift tube may well have caused this pit crater. At this time, it is unique in Hawaii.

\section{SMALL VERTICAL CONDUITS}

The present Glossary of Geology definition of pit crater technically could include much smaller vertical volcanic shafts than those commonly called pit craters. The most notable examples in Hawaii are at the head of the famous Kaupulehu xenolith nodule beds on Hualalai Volcano (Fig. 15-18). Some of these lead down to short horizontal passages terminating in small chambers with notable volcanic features. One is a more complex structure $30 \mathrm{~m}$. deep (Fig. 15). These appear to be drained vents. Some occur in linear groups, separated by narrow septae or sills. The pahoehoe cap of one such vent is largely intact (Fig. 18). These are properly termed open vertical volcanic conduits (Skinner, 1993), not pit craters.

\section{PIT CRATERS AS AN INTERFACE OF VOLCANOLOGY AND SPELEOLOGY}

The term pit crater was first used before 1850 (Dana, 1849), and volcanologists' disagreements about their parameters are almost as old. This might seem to be an ideal 


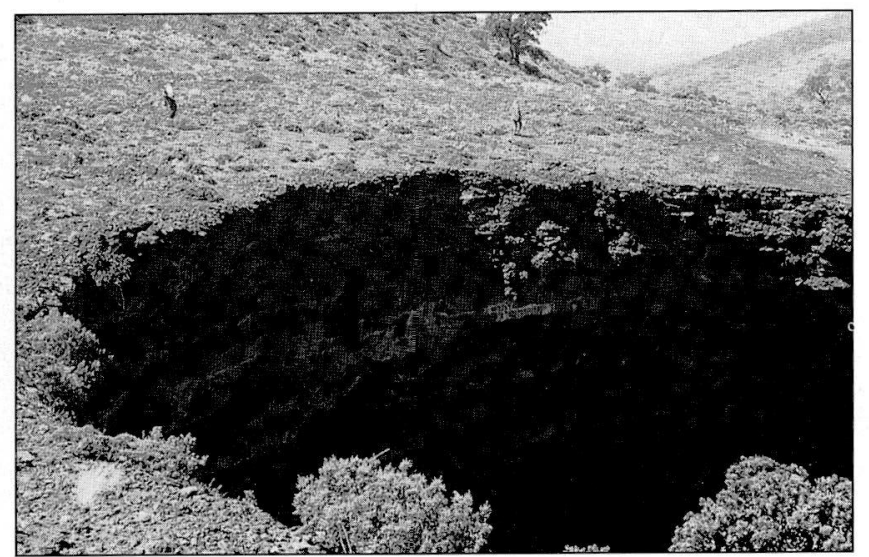

Fig. 9. Upslope end of one of the Malekule pit craters of Hualalai volcano, Hawaii. There is no raised rim of ejecta, but where the persons are walking, the ground is littered with small volcanic bombs. Photo by the author.

Fig. 10. Aerial view of bowlshaped Kaupulehu Crater (bottom center) and "Parrot Pit", a "punchè-out" pit crater, on the northwest rift zone of Hualalai Volcano. The inner open vertical volcanic conduit of Kaupulehu Crater is hidden in the shadow of the elevated rim. Photo by the author.

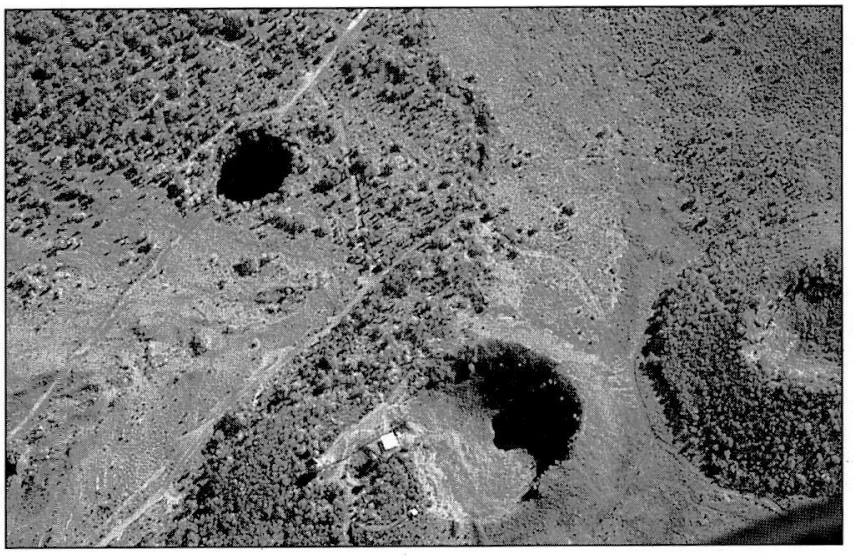

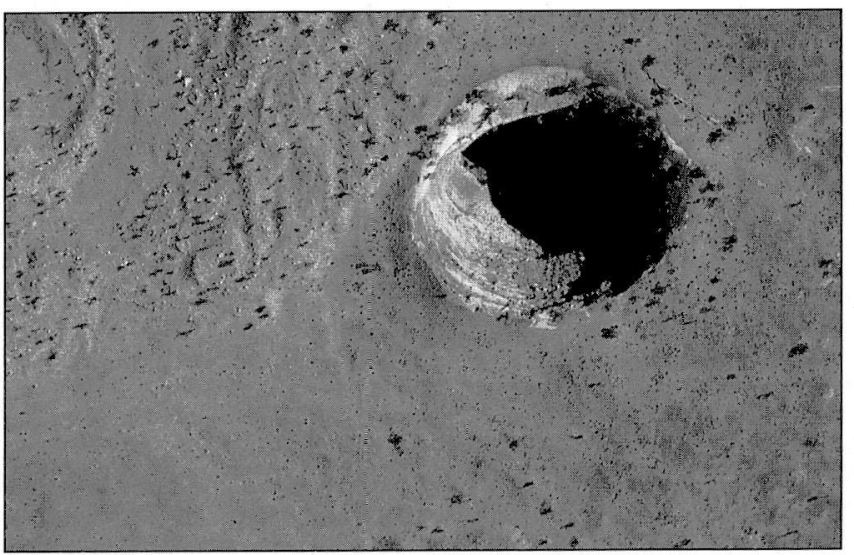

Fig. 11. Aerial view of $\mathrm{Na}$ One Pit, Hualalai volcano, showing small raised rim of ejecta. Because of this small raised rim, some volcanologists do not consider it a pit crater. The inner open vertical volcanic conduit is hidden in shadow. Photo by the author. 


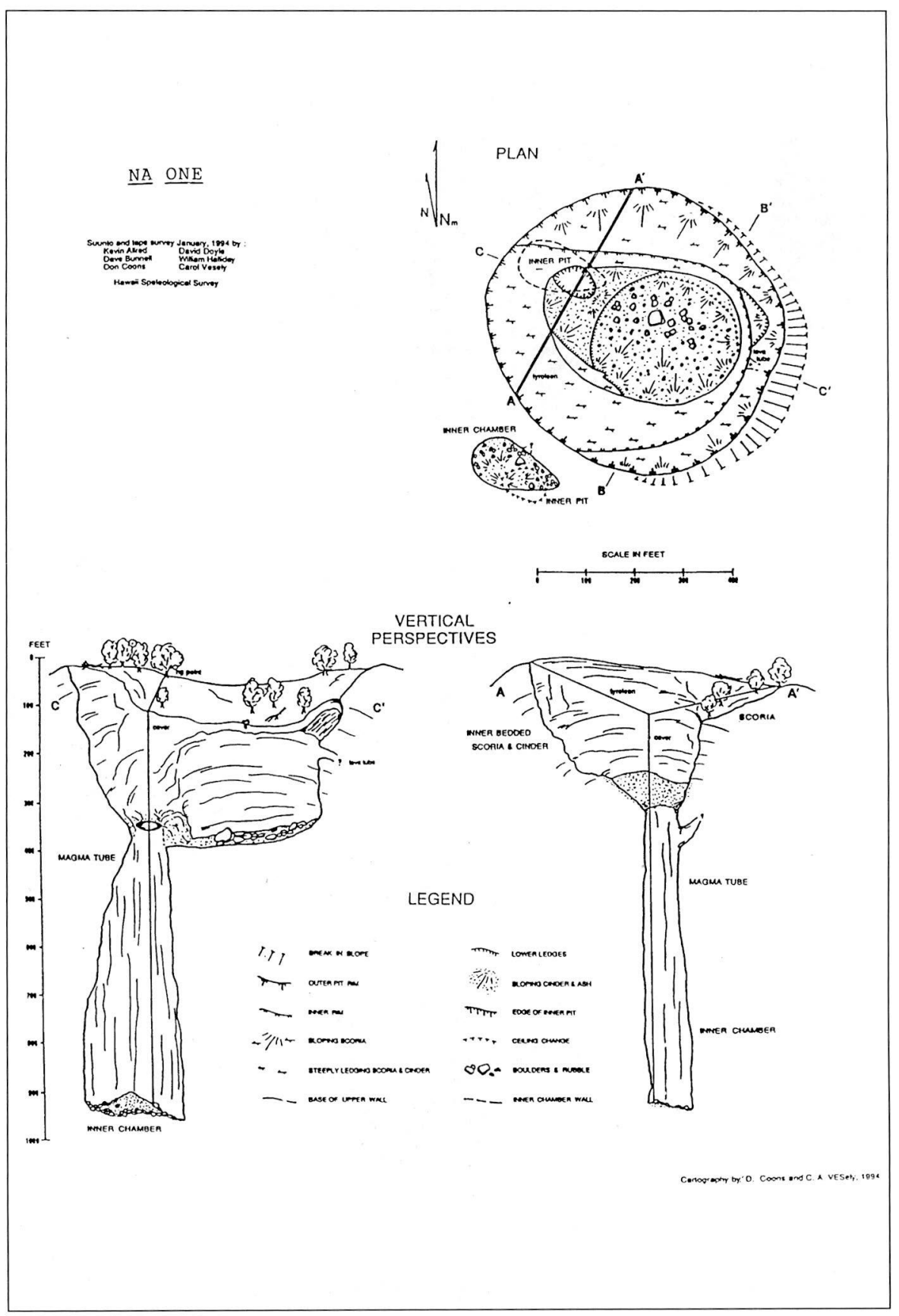

Fig. 12. Map of Na One Pit. Suunto and tape survey January 1994 by: Kevin Allred, Dave Bunnell, Don Coons, David Doyle, William Halliday, Carol Vesely. Hawaii Speleological Survey. 


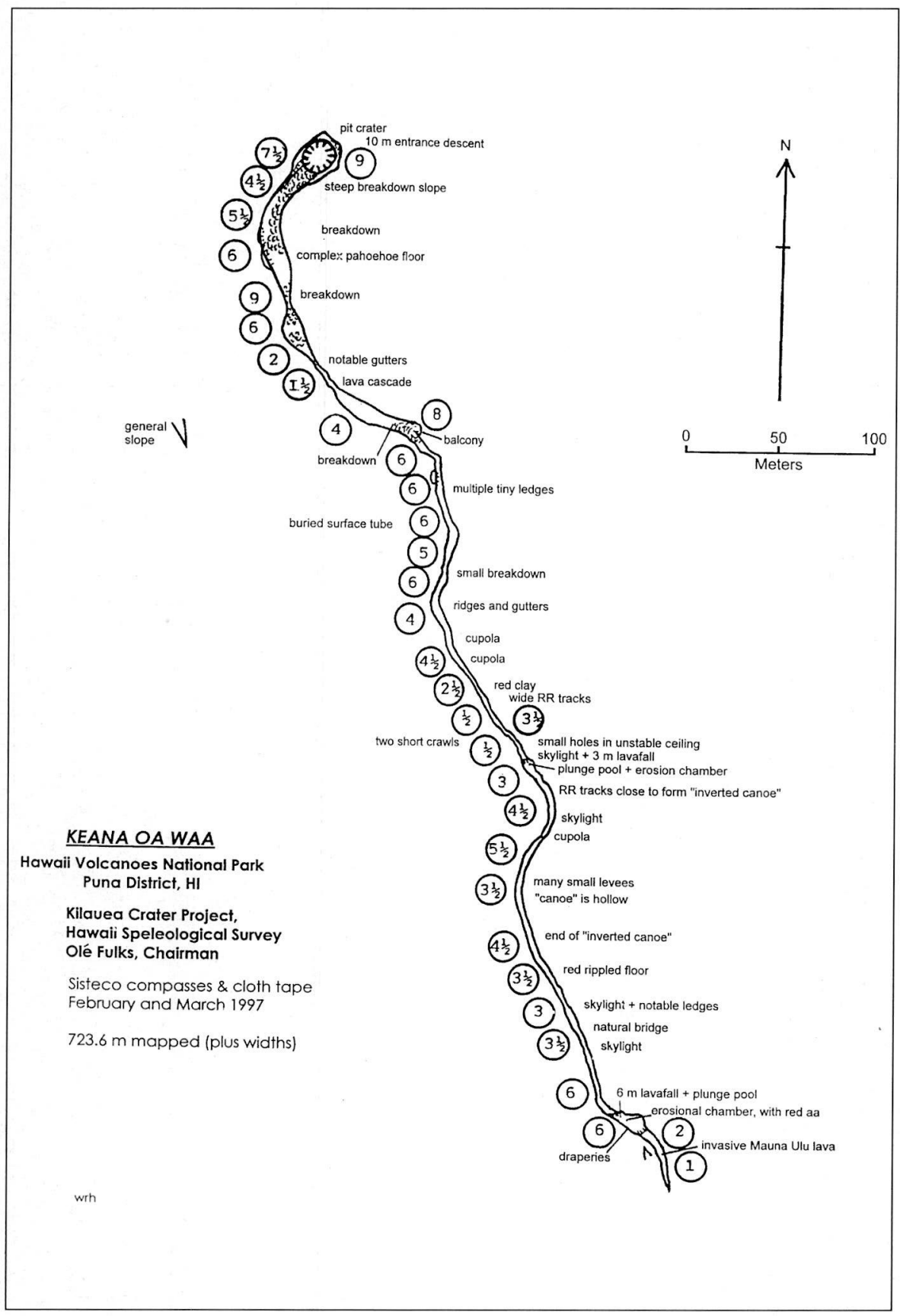

Fig. 13. Map of Keana Oa Waa, a complex consisting of a small pit crater with a localized rim of accreted plates plus a lava tube. 


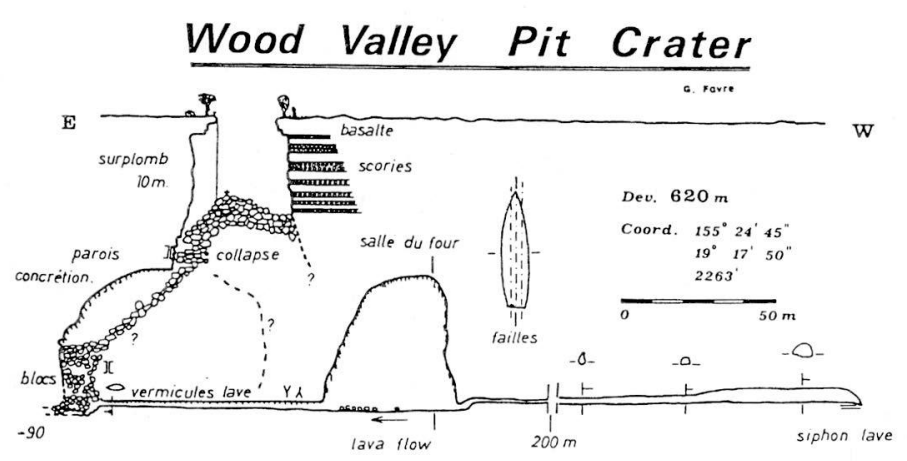

Fig. 14. Map of Wood Valley Pit Crater, from Favre, 1993.

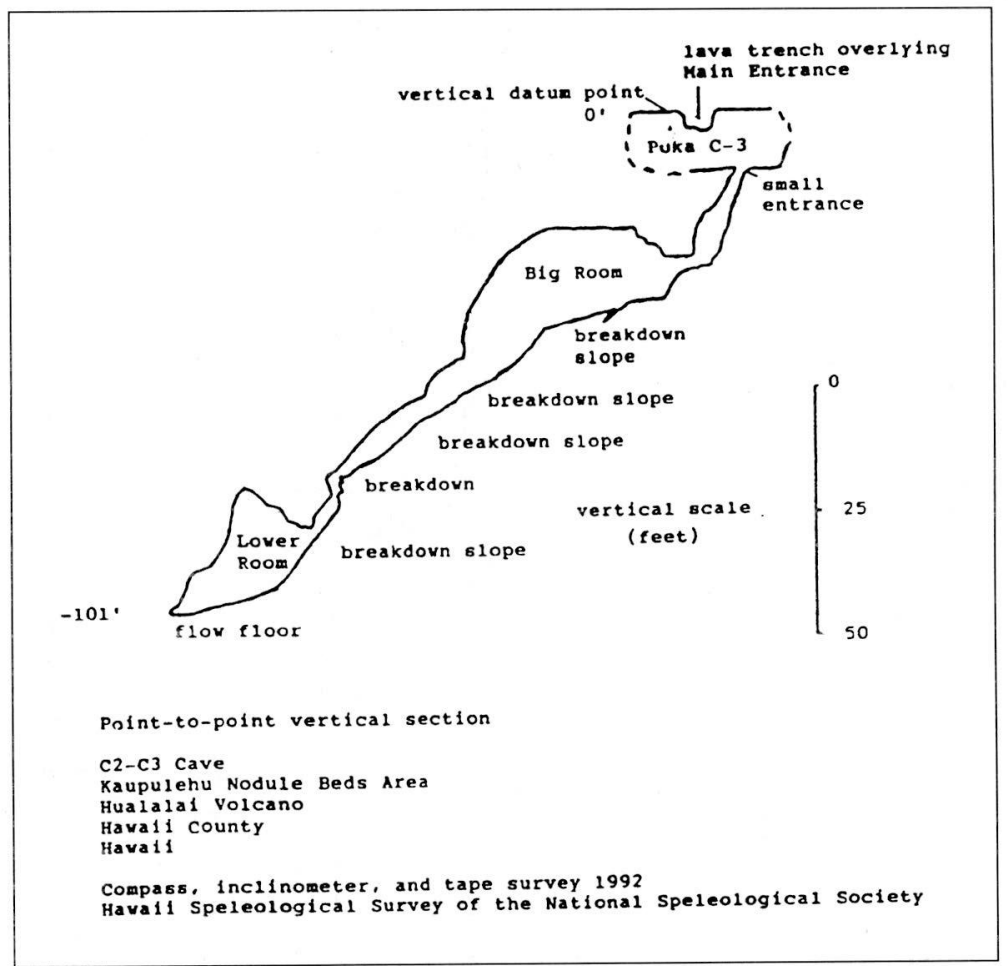

Fig. 15. Point-to-point vertical section of C2-C3 Cave, the deepest open vertical volcanic conduit known at the head of the Kaupulehu nodule beds. The ceiling and one wall of the Big Room are largely an accreted bed of dense lava containing ultramafic xenoliths of several mineralogical types. Nodule beds are present in several locations in this cave. 
morass for speleologists to avoid. Yet, the confusion between roof features of ordinary lava tube caves and pit craters is clearly in the interface of vulcanospeleology and volcanology. Further, other vertical volcanic features are rapidly emerging as another interface. Cavers' "Nylon Highway" of single rope techniques makes many examples much more accessible for study by speleologists than by volcanologists. When using speleological expertise credibly, input by vulcanospeleologists already has been acceptable to editors of Glossary of Geology. Further input concerning the limited relationship between pit craters and lava tube caves is clearly appropriate. Future editions should specify that, except for very unusual deep-lying rift tubes, pit craters are NOT skylights nor collapse windows of passages of lava tube caves.

Some other supposed definitions in Glossary of Geology actually are non-definitions; an example is that of agglomerate. Its listing notes that agglomerate has been variously defined, and specifies that the term should be defined in context to avoid confusion. Provided that features of ordinary lava tube caves and open vertical volcanic conduits as defined by Skinner (1993) are specifically excluded, perhaps the same should be said for pit crater. I propose that the new President of the IUS Commission on Volcanic Caves suggest this to the editors of Glossary of Geology.

And I also propose that we as speleologists continue and expand our recent field support for volcanologists. Our special technical skills can be of great value in these vertical features, whatever they are called. Other open vertical volcanic features yet unplumbed will tax our combined knowledge and skills (Fig. 19) and require maximum cooperation in this interface of volcanology and speleology.

\section{ACKNOWLEDGMENTS}

Lengthy discussions with Chris Okubo and Charles V. Larson greatly clarified my thoughts on these and related matters. Studies in Hawaii Volcanoes National Park were made possible by Jim Martin (now Superintendent of that park) and Bobby Camara, its Cave Resource Specialist. Ron Greeley brought the Kaupulehu open vertical volcanic conduits to my attention and he and Steve Kadel joined in part of the subsurface studies. Jeff Taylor obtained permission for access to Bishop Estate lands. My thanks to all.

\section{REFERENCES}

Dana, J.D. 1849. Geology. Volume X, U.S. Exploring Expedition during the years 1838, 1839, 1840, 1841 and 1842, under the command of Charles Wilkes, USN. Philadelphia, printed by C. Sherman.

Doerr, J.E. Jr. n.d. (ca. 1930). Exploring the Devil's Throat. Hawaii National Park Nature Notes, Vol. 2, no. 3, P. 23.

Favre, G. 1993. Some observations on Hawaiian pit craters and relations with lava tubes. Proceedings, 3rd Internat. Symp. on Vulcanospeleology, Bend, OR, 1982. Seattle, International Speleological Foundation, p. 37.

Halliday, W. R. 1993. Kaluaiki and Thurston Lava Tube: an unrecognized jameo? Proceedings, 3rd Internat. Symp. on Vulcanospeleology, Bend, OR, 1982. Seattle, International Speleological Foundation, p. 52.

Jaggar, T.A. 1947. Origin and development of craters. Geol. Soc. of Amer. Memoir no. 21, 508 p. Plate X.

Jackson, J.A. (editor). 1997. Glossary of Geology, 4th Edition. Alexandria, VA, Amer. Geol. Inst., 769 p.

Moore, R.B. and D.A. Clague. 1991. Geological map of Hualalai Volcano. U.S. Geol. Survey Misc. Investigations Series Map 1-2213.

Skinner, C. 1993. Open vertical volcanic conduits: a preliminary investigation of an unusual volcanic form from Newberry Volcano and the central High Cascades of Oregon. Proceedings, 3rd International Symp. on Vulcanospeleology, Bend, OR, 1982. Seattle, International Speleological Foundation, p. 7.

Whitfield, P. 1980. Western Cone Crater, Hawaii, 19 and 20 December 1979. Cascade Caver, Vol. 19 no. 4 (April), p. 49 


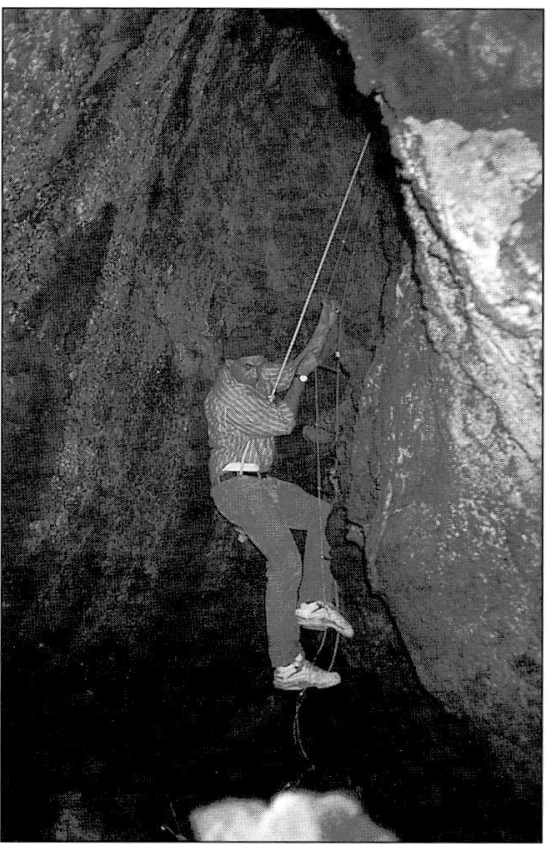

Fig. 16. Descending one of the open vertical volcanic conduits in the Kaupulehu xenolith nodule beds vent area. Photo by the author.

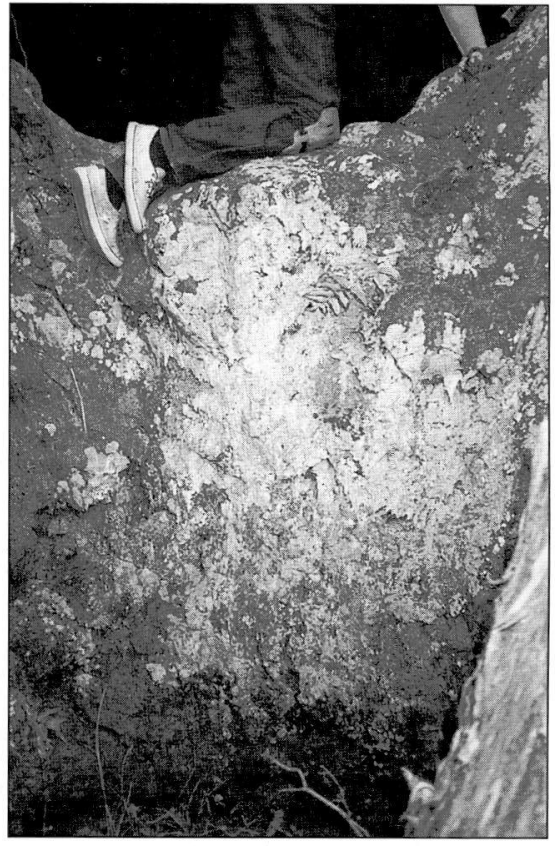

Fig. 17. Septum or sill separating open vertical volcanic conduits in Kaupulehu xenolith nodule beds vent area. Photo by the author.

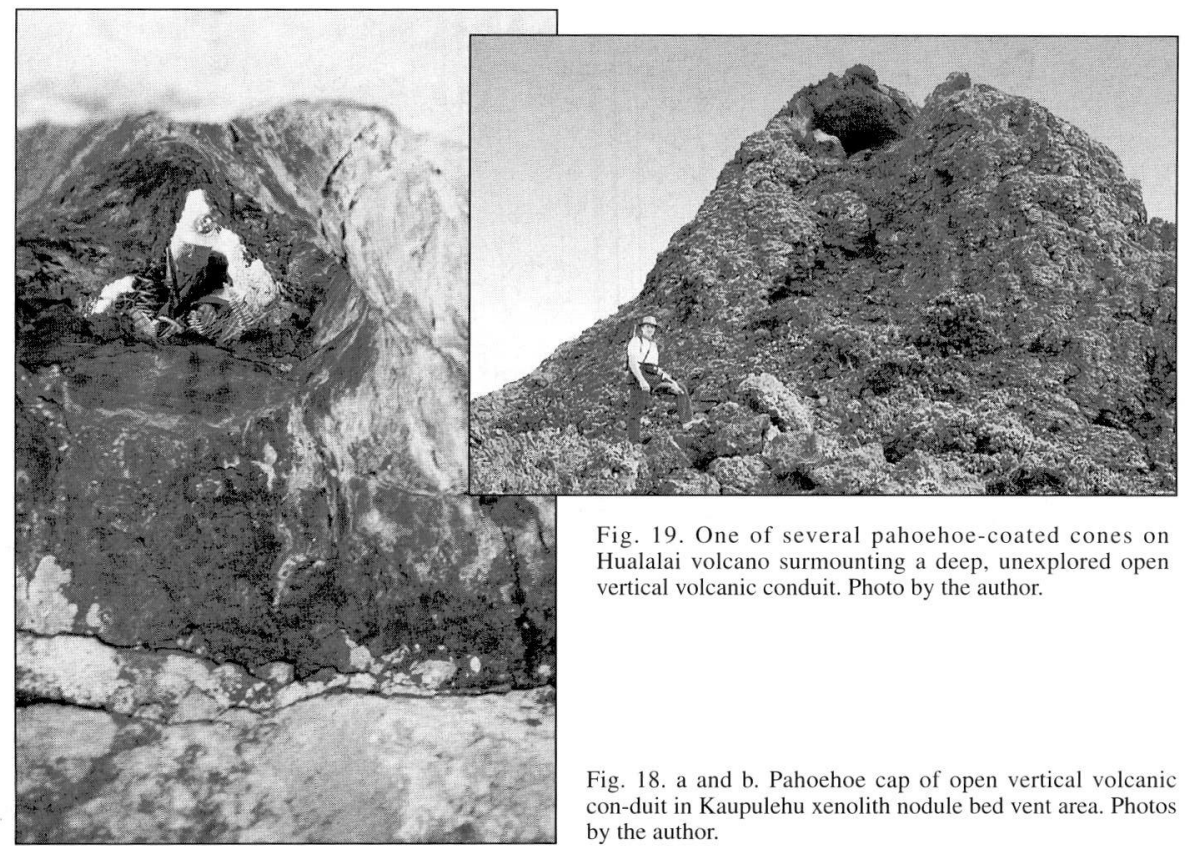

